\title{
Determination of Heavy Metals Contents of Some Monofloral Honey Produced in Turkey
}

\author{
Tuba Pehlivan $^{1 *}$, Aziz Gül $^{2}$ \\ ${ }^{1}$ Nurdağı Vocational School, Gaziantep University, Nurdağı, Gaziantep, Turkey. \\ ${ }^{2}$ Faculty of Agriculture, University of Mustafa Kemal, Antakya, Hatay, Turkey.
}

\begin{tabular}{|c|c|}
\hline ARTICLE INFO & ABSTRACT \\
\hline Article history: & \multirow{6}{*}{$\begin{array}{l}\text { In the present work, some element contents }(\mathrm{Cd}, \mathrm{Se}, \mathrm{Cr}, \mathrm{Pb}, \mathrm{Cu}, \mathrm{Mn}, \mathrm{Ni}, \mathrm{Zn}, \mathrm{Fe}) \text { of } 23 \text { different monofloral honey } \\
\text { samples from different regions of Turkey were assessed. Origins of monofloral honey research materials are as } \\
\text { follows; Pimpinella sp., Castanea sp., Astragalus sp., Onobrychis sp., Mentha sp., Coridothymus capitatus, } \\
\text { Robinia pseudoacacia, Cedrus libani, Gossypium sp., Thymus sp., Euphorbia sp., Tilia sp., Eucalyptus sp., } \\
\text { Ferula sp., Centaurea solstitialis, Petroselinum sp., Vitexagnus-castus, Helianthus annuus, Citrus sp., Pinus sp., } \\
\text { Rhododendron sp., Arbutus sp., Ceratonia siliqua. Metal contents of samples were determined by wet } \\
\text { combustion method in ASS machine. As a result of the study, heavy metal contents of honey samples were as } \\
\text { follows; } \mathrm{Cd}<\mathrm{Se}<\mathrm{Cr}<\mathrm{Pb}<\mathrm{Cu}<\mathrm{Mn}<\mathrm{Ni}<\mathrm{Zn}<\mathrm{Fe} \text {. In addition, although none of the heavy metals were found in some } \\
\text { honey samples, honey samples were found to be reliable in terms of heavy metal residues. }\end{array}$} \\
\hline Received on: 07/05/2015 & \\
\hline Revised on: 24/05/2015 & \\
\hline Accepted on: 21/06/2015 & \\
\hline Available online: $28 / 08 / 2015$ & \\
\hline $\begin{array}{l}\text { Key words: } \\
\text { Monofloral, Honey, Heavy } \\
\text { metal, Turkey }\end{array}$ & \\
\hline
\end{tabular}

\section{INTRODUCTION}

Honey is used as food an important ingredient in different kinds of manufactured foods. It may be a significant source of vitamin and micro- and macro-elements essential for human health (Nanda et al., 2003; Formicki et al., 2013). The bee is active throughout the area surrounding the hive: for, although an opportunist in the sense that it prefers to gather pollen in the flowered fields nearby, the bee can range over long distances, even up to ten kilometers under exceptional circumstances: a hive can keep an area of seven square kilometers "under its control" (Crane, 1984; Celli and Maccagnani 2003).Bees are in close relationship with their environment, as here shown. Honey and bee products have the image of being natural, healthy and clean. However, today bee products are produced in an environment polluted by different sources of contamination (Bogdanov, 2006). Accumulation of metals may derive from external sources such as industrial pollution, incorrect treatment and agrochemicals (Bratu and Georgescu, 2005; Czipa et al., 2015). Air and soil contain heavy

\section{* Corresponding Author}

Tuba Pehlivan, Plant and Animal Product, Nurda $\breve{g}$ Vocational School, Gaziantep University, Nurdağı/ Gaziantep, Turkey.

Email: tpehlivan1@hotmail.com metals, mainly from industry and traffic which can also contaminate the bee colony and its products (Bogdanov, 2006). Heavy metal present in atmosphere can deposit on the hairy bodies of bees and be brought back to the hive with pollen, or they may be absorbed together with the nectar of the flowers, or throught the water or the honeydew (Porrini et al., 2003). Heavy metals are defined as metals with a density higher than $5 \mathrm{~g} \mathrm{~cm}^{-3} .53$ of the 90 naturally occurring elements are heavy metals (Weast, 1984). Human cells employ metals such as zinc, copper and iron to control significant metabolism and signaling functions making them essential for life (Sataray et al., 2003; Haddad, 2012). Many heavy metals play an important biological role, the particular importance of iron and copper ions in biological processes (Halliwell and Gutteridge 1999; Haddad, 2012). On the other hand macro molecules in cell are damaged by metals induced production oxygen and nitrogen containing free radicals (oxidants) and/or metal induced depletion of the cells antioxidant defense programmed cell death or necrotic cell death are usual consequences (Pulido and Parrish, 2003).

\section{MATERIAL AND METHODS}

Total number of 23 different monofloral honey samples from different regions of Turkey were assessed in the present study and the samples were not subjected to any heating process. 
Table 1: Obtained honey samples in the study.

\begin{tabular}{|c|c|c|c|c|c|}
\hline Honey & Honey Origin & Localization & Honey & HoneyOrigin & Localization \\
\hline Eucalyptus & Eucalyptus sp. & Adana/Center & Chestnut & Castanea sp. & Ordu/Fatsa \\
\hline Sunflower & H. annuus & Adana/Ceyhan & Acacia & R. pseudoacacia & Ordu/Fatsa \\
\hline Citrus & Citrus sp. & Adana/Yuregir & Rhododendron & Rhododendron sp. & Giresun/Bulancak \\
\hline Strawberry tree & Arbutus sp. & Mersin/Silifke & Linden & Tilia sp. & Kastamonu/Azdavay \\
\hline Carob bean & C. siliqua & Mersin/Silifke & Wild Mint & Mentha sp. & İstanbul/Catalca \\
\hline Ferula & Ferula sp. & Mersin/Silifke & Yellowstar-thistle & C. solstitialis & Diyarbakır/Lice \\
\hline Anise & Pimpinella sp. & Antalya/Korkuteli & Cotton & Gossypium sp. & Diyarbakır/Devegecidi \\
\hline Cedrus & C. libani & Antalya/Elmalı & Sainfoin & Onobrychis sp. & Van/Baskale \\
\hline Cesme thyme & C. capitatus & İzmir/Çesme & Thyme & Thymus sp. & Batman/Gercus \\
\hline Chasteberry & V. agnus-castus & İzmir/Torbalı & Euphorbia & Euphorbia sp. & Mardin/Midyat \\
\hline Parsley & Petroselinum sp. & Hatay/İskenderun & Pine & Pinus sp. & Mugla/Marmaris \\
\hline Astragalus & Astragalus sp. & Konya/Hadim & & & \\
\hline
\end{tabular}

The honey samples were obtained from the manufacturers in 2012. The location of obtained honey samples were presented in Table 1. Honey samples were preserved in glass jars at room temperature. All samples were studied in triplicate.

\section{Methods}

\section{Heavy metal analysis of monofloral honey samples}

Heavy metal analysis of monofloral honey samples were evaluated according to wet combustion method of Dean et al. (2003). In the analysis of samples, lead $(\mathrm{Pb})$, cadmium $(\mathrm{Cd})$, zinc $(\mathrm{Zn})$, iron $(\mathrm{Fe})$, chromium $(\mathrm{Cr})$, copper $(\mathrm{Cu})$, manganese $(\mathrm{Mn})$, nickel (Ni), selenium (Se) heavy metals were determined by Atomic Absorption Spectrophotometer (AAS) instrument. Results of the samples were determined by comparing the results with measurements of heavy metal standards. $5 \mathrm{~g}$ of honey sample was mixed with $10 \mathrm{ml}$ nitric oxide and heated at $95{ }^{\circ} \mathrm{C}$ for a period of 1 hour until the solution gets yellow color. After cooling the mixture, $5 \mathrm{ml}$ concentrated nitric acid $\left(\mathrm{HNO}_{3}\right)$ was added and heated to $180^{\circ} \mathrm{C} .1 \mathrm{~mL}$ of $\mathrm{HNO} 3$ were added if necessary until clear color or pale straw color. After cooling the sample, $1 \mathrm{ml}$ of $\mathrm{H}_{2} \mathrm{O}_{2}$ $(500 \mathrm{~g} / \mathrm{L})$ was added and heated to $200{ }^{\circ} \mathrm{C}$. This step was repeated until malodorous brown fumes over. The samples cooled again and mixed with $10 \mathrm{ml}$ distilled water and $0.5 \mathrm{ml}$ concentrated $\mathrm{HNO}_{3}$ and slowly heated to $200{ }^{\circ} \mathrm{C}$ until the white malodorous gases obtained. After that, the samples cooled again and mixed with 10 $\mathrm{ml}$ distilled water and $1 \mathrm{ml} \mathrm{H}_{2} \mathrm{O}_{2}(500 \mathrm{~g} / \mathrm{L})$ slowly heated to $240^{\circ} \mathrm{Cuntil}$ white malodorous gases obtained. At the end, samples were cooled and transferred to $25 \mathrm{~mL}$ volumetric flask, and analyzed in AAS instrument (Dean, 2003). Heavy metal contents of samples were compared to standards and results were determined in $\mathrm{ppm}(\mathrm{mg} / \mathrm{kg})$.

\section{Analysis of sediment for the identification of honey samples}

The monofloral honey samples were classified according to their botanical origin using the method of Maurizio, (1951). Pollen grains were microscopically observed and compared with there ferenceslides for identification. Botanical classification was achieved when the pollen spectrum contained $>45 \%$ of the corresponding dominant pollen. Floral origins of honey samples are; Pimpinella sp., Castanea sp., Astragalus sp., Onobrychis sp., Mentha sp., Coridothymus capitatus, Robinia pseudoacacia,
Cedrus libani, Gossypium sp., Thymus sp., Euphorbia sp., Tilia sp., Eucalyptus sp., Ferula sp., Centaurea solstitialis, Petroselinum sp., Vitexagnus-castus, Helianthus annuus, Citrus sp., Pinus sp., Rhododendron sp., Arbutus sp., Ceratonia silique (Table 2).

Table 2: Botanical origin of honey samples.

\begin{tabular}{|c|c|c|c|}
\hline Monofloral honey & 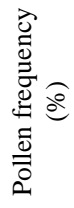 & Monofloral honey & 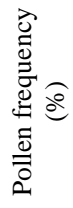 \\
\hline Pimpinella sp. & 0.45 & Tilia sp. & 0.66 \\
\hline Castanea sp. & 0.75 & Eucalyptus sp. & 0.73 \\
\hline Astragalus sp. & 0.52 & Ferula sp. & 0.47 \\
\hline Onobrychis sp. & 0.47 & Centaurea solstitialis & 0.46 \\
\hline Mentha sp. & 0.51 & Petroselinum sp. & 0.79 \\
\hline Coridothymus capitatus & 0.63 & Vitexagnus-castus & 0.86 \\
\hline Robinia pseudoacacia & 0.54 & Helianthus annuus & 0.86 \\
\hline Cedrus libani & 0.58 & Citrus sp. & 0.57 \\
\hline Gossypium sp. & 0.53 & Rhododendron sp. & 0.56 \\
\hline Thymus sp. & 0.48 & Arbutus sp. & 0.61 \\
\hline Euphorbia sp. & 0.60 & Ceratonia siliqua & 0.46 \\
\hline
\end{tabular}

\section{RESULTS AND DISCUSSION}

As a result of the study obtained results of the heavy metal contents of samples were presented in Table 3. In this study, the average cadmium $(\mathrm{Cd})$ contents of honey samples were determined to be $0.0002 \pm 0.0 \mathrm{mg} / \mathrm{kg}$ (ppm). Generally, $\mathrm{Cd}$ is toxic heavy metal and should not be present in food samples. Worldwide there are no specific MRL (Maximum Residue Limit) levels for these heavy metals in honey. The average recommended daily intake in foods is reported to be $60 \mathrm{mg} /$ day for cadmium (Silici et al. 2008). Average lead $(\mathrm{Pb})$ contents of samples were determined as $0.04 \pm 0.09 \mathrm{mg} / \mathrm{kg}$. The highest lead content in honey samples were determined in Cesme thyme and Wild mint honey samples which are Wild mint obtained from Istanbul and Cesme thyme obtained from İzmir, respectively. TheMRL proposal for EU is at $1 \mathrm{mg} / \mathrm{kg}$ for lead (Byrne, 2000, Bogdanov, 2006). Lead contents of all honey samples are appropriate with the standards of EU. On average, the $\mathrm{Pb}$ concentration was low and unproblematic in honey. Bee products are less suitable to serve as indicators for the measurement of $\mathrm{Pb}$ and $\mathrm{Cd}$ pollution due to considerable natural 
variation (Porrini et al., 2002; Bogdanov 2006). Average iron (Fe), copper $(\mathrm{Cu})$ and zinc $(\mathrm{Zn})$ contents of samples in our study was $2.85 \pm 0.5,0.15 \pm 0.1$ and $0.48 \pm 0.3 \mathrm{mg} / \mathrm{kg}$. $\mathrm{Cu}$ contents of honey samples in our study was determined to below the limit standards. The average recommended daily intake in foods is reported to be $30 \mathrm{mg} /$ day for copper and $12-15 \mathrm{mg} /$ day for zinc (Silici et al. 2008).

On the other hand, The Food and Agriculture Organization (FAO) and the World Health Organization (WHO) have set a limit for heavy metal intake based on body weight (b.w.). For an average adult (60 kg b.w.), the provisional tolerable daily intake for $\mathrm{Pb}, \mathrm{Fe}, \mathrm{Cu}$, and Znare $214 \mathrm{mg}, 48 \mathrm{mg}, 3 \mathrm{mg}$, and $60 \mathrm{mg}$, respectively (Joint FAO/WHO Expert Committee on Food Additives 1999) (Silici et al., 2014). Additionally, average contents of other heavy metals in honey samples were as follows; chromium $(\mathrm{Cr}) 0.0086 \pm 0.01 \mathrm{ppm}$, manganese $(\mathrm{Mn}) 0.187 \pm 0.18$ ppm,nickel $(\mathrm{Ni}) 0.26 \pm 0.23 \mathrm{ppm}$ and selenium $0.0003 \pm 0.0$. Type and quality of equipment used to store honey after harvesting, processing and/ or preparation of honey can generate high $\mathrm{Cr}$ content. Likewise, storing honey in galvanized containers can be source of Zn contamination (Silici et al., 2008). The MRL levels in Switzerland for Nivaries is between $0.1 \mathrm{mg} / \mathrm{kg}$ (beer) to 0.2 $\mathrm{mg} / \mathrm{kg}$ (edible fat). Following levels have been found in honey: Ni: 0.004-3.23 mg/kg (Porrini et al., 2002; Bogdanov, 2006). As a result of the heavy metal analysis, although heavy metal contents of wild mint honey which is obtained from Istanbul and Cesmethyme honey which is obtained Izmir is appropriate according to TGK and Codex standards, both have the highest heavy metal content among other honey samples in the study. Because of their production in close proximity to industrial and residential areas, this honey samples are thought to be exposed to heavy metal contamination.

Some studies related to heavy metal content in honey samples were presented in Table 4. As indicated in the table some of the values are in parallel with our findings. Generally, findings of the present study suggest that heavy metal contents of the honey samples assessed in this study are not high compared with the literature (Table 4). Although honey is and important food and consumed for the health, heavy metal contamination in honey and toxic levels of these heavy metals in honey samples can lead and to serious health problems.

Table 3: Heavy metal contents of honey samples $(\mathrm{mg} / \mathrm{kg})$

\begin{tabular}{|c|c|c|c|c|c|c|c|c|c|}
\hline HONEY & $\mathbf{P b}$ & Zn & $\mathbf{F e}$ & Cd & $\mathrm{Cu}$ & $\mathrm{Cr}$ & Mn & $\mathbf{N i}$ & Se \\
\hline Pimpinella $\mathrm{sp}$. & 0.08 & 0.84 & 2.81 & 0.0001 & 0.29 & 0.024 & 0.35 & 0.53 & 0.0001 \\
\hline Castanea sp. & $<0.001$ & 0.34 & 3.28 & $<0.0001$ & 0.16 & 0.01 & 0.18 & 0.06 & $<0.0001$ \\
\hline Astragalus sp. & $<0.001$ & 0.75 & 3.12 & $<0.0001$ & 0.36 & 0.003 & 0.32 & 0.41 & 0.0001 \\
\hline Onobrychis sp. & $<0.001$ & 0.57 & 2.98 & $<0.0001$ & 0.28 & 0.005 & 0.17 & 0.36 & 0.0001 \\
\hline Menthasp. & 0.33 & 1.16 & 3.61 & 0.0023 & 0.32 & 0.036 & 0.63 & 0.87 & 0.0028 \\
\hline C. capitatus & 0.25 & 0.98 & 3.54 & 0.0015 & 0.35 & 0.026 & 0.67 & 0.85 & 0.0032 \\
\hline R. pseudoacacia & $<0.001$ & 0.61 & 3.18 & $<0.0001$ & 0.18 & 0.001 & 0.34 & 0.23 & $<0.0001$ \\
\hline C. libani & $<0.001$ & 0.097 & 1.94 & $<0.0001$ & 0.04 & 0.003 & 0.01 & 0.08 & $<0.0001$ \\
\hline Gossypium sp. & 0.02 & 0.53 & 3.17 & 0.0012 & 0.03 & 0.004 & 0.07 & 0.16 & $<0.0001$ \\
\hline Thymussp. & $<0.001$ & 0.56 & 2.87 & $<0.0001$ & 0.05 & 0.003 & 0.04 & 0.12 & $<0.0001$ \\
\hline Euphorbia sp. & $<0.001$ & 0.5 & 2.75 & $<0.0001$ & 0.03 & 0.007 & 0.07 & 0.15 & $<0.0001$ \\
\hline Tiliasp. & 0.12 & 0.48 & 2.97 & $<0.0001$ & 0.14 & 0.004 & 0.14 & 0.22 & $<0.0001$ \\
\hline Eucalyptussp. & 0.09 & 0.085 & 2.81 & $<0.0001$ & 0.03 & 0.014 & 0.12 & 0.13 & $<0.0001$ \\
\hline Ferulasp. & $<0.001$ & 0.62 & 3.12 & $<0.0001$ & 0.17 & 0.004 & 0.21 & 0.25 & 0.0001 \\
\hline C. solstitialis & $<0.001$ & 0.81 & 3.25 & 0.0001 & 0.32 & 0.003 & 0.36 & 0.47 & 0.0002 \\
\hline Petroselinum sp. & $<0.001$ & 0.08 & 2.2 & $<0.0001$ & 0.02 & 0.002 & 0.08 & 0.09 & $<0.0001$ \\
\hline V. agnus-castus & $<0.001$ & 0.05 & 1.74 & $<0.0001$ & 0.01 & 0.001 & 0.01 & 0.02 & $<0.0001$ \\
\hline H. annuus & $<0.001$ & 0.39 & 1.71 & $<0.0001$ & 0.02 & 0.01 & 0.02 & 0.04 & $<0.0001$ \\
\hline Citrussp. & $<0.001$ & 0.32 & 2.1 & $<0.0001$ & 0.03 & 0.02 & 0.05 & 0.17 & $<0.0001$ \\
\hline Rhododendron sp. & $<0.001$ & 0.1 & 3.27 & $<0.0001$ & 0.08 & 0.006 & 0.11 & 0.18 & $<0.0001$ \\
\hline Arbutus sp. & $<0.001$ & 0.24 & 2.77 & $<0.0001$ & 0.05 & 0.004 & 0.06 & 0.12 & $<0.0001$ \\
\hline C. siliqua & $<0.001$ & 0.31 & 2.95 & $<0.0001$ & 0.11 & 0.003 & 0.13 & 0.21 & 0.0001 \\
\hline Pinus sp. & $<0.001$ & 0.52 & 3.46 & $<0.0001$ & 0.18 & 0.005 & 0.16 & 0.25 & 0.0001 \\
\hline Min & $<0.001$ & 0.05 & 1.71 & $<0.0001$ & 0.01 & 0.001 & 0.01 & 0.02 & $<0.0001$ \\
\hline Max & 0.33 & 1.16 & 3.61 & 0.00023 & 0.36 & 0.036 & 0.67 & 0.87 & 0.0032 \\
\hline Mean & $0.04 \pm 0.09$ & $0.48 \pm 0.3$ & $2.85 \pm 0.5$ & $0.0002 \pm 0$ & $0.15 \pm 0.1$ & $0.0086 \pm 0.01$ & $0.187 \pm 0.18$ & $0.26 \pm 0.2$ & $0.0003 \pm 0$ \\
\hline
\end{tabular}

Table 4: Some studies related to heavy metal content in honey samples (ppm).

\begin{tabular}{|c|c|c|c|c|c|c|c|c|c|}
\hline $\begin{array}{l}\text { HEAVY } \\
\text { METALS }\end{array}$ & $\begin{array}{l}\text { This } \\
\text { Study }\end{array}$ & $\begin{array}{l}\text { Bilandžićet } \\
\text { al. (2014) }\end{array}$ & $\begin{array}{l}\text { Ru et al. } \\
\text { (2013) }\end{array}$ & $\begin{array}{c}\text { Chudzinska and } \\
\text { Baralkiewicz (2011) }\end{array}$ & $\begin{array}{c}\text { Gül } \\
\text { (2008) }\end{array}$ & Silici et al. (2008) & $\begin{array}{l}\text { Pisani et } \\
\text { al. (2008) }\end{array}$ & $\begin{array}{l}\text { Terrab et } \\
\text { al. (2005) }\end{array}$ & Tüzen (2002) \\
\hline $\mathrm{Pb}$ & 0.04 & 0.81 & $0.03^{*}$ & 0.59 & 0.29 & $0.00151-0.0553^{*}$ & 0.08 & 0.08 & $0.0303-0.0586$ \\
\hline $\mathrm{Cu}$ & 0.15 & 20.6 & 0.05 & 1.31 & $0.24 *$ & $0.009-0.035^{*}$ & 0.91 & 4.18 & $0.25-1.30$ \\
\hline $\mathrm{Cr}$ & 0.0086 & - & - & 0.036 & 0.03 & $* 0.00124-0.013$ & - & 0.1 & - \\
\hline $\mathrm{Zn}$ & 0.48 & 6.78 & 0.01 & 3.27 & 1.53 & $* 0.47-6.57$ & 1.82 & 5.65 & $1.15-4.95$ \\
\hline $\mathrm{Fe}$ & 2.85 & 0.003 & - & - & $3^{*}$ & $* 1.21-12.9$ & $3.07 *$ & 9.19 & $3.45-8.94$ \\
\hline $\mathrm{Mn}$ & 0.187 & - & - & 6.5 & 1.27 & $1.11-61$ & 1.54 & 1.14 & $0.32-0.70$ \\
\hline $\mathrm{Ni}$ & 0.26 & - & - & 0.84 & $0.32 *$ & $0.00121-0.131$ & $0.31 *$ & $0.33 *$ & - \\
\hline $\mathrm{Cd}$ & 0.0002 & 0.002 & 0.001 & 0.02 & 0.00 & $* 0.00028-0.0023$ & 0.003 & 0.04 & $0.00523-0.00982$ \\
\hline $\mathrm{Se}$ & 0.0003 & - & - & - & - & $0.014-0.323$ & - & 0.05 & - \\
\hline
\end{tabular}




\section{CONCLUSION}

In conclusion, heavy metal contents of honey samples were $0.0002,0.04,0.48,2.85,1.15,0.187,0.059,0.26,0.0086$, and $0.0003 \mathrm{ppm}$ for cadmium $(\mathrm{Cd})$, lead $(\mathrm{Pb})$, zinc $(\mathrm{Zn})$, iron $(\mathrm{Fe})$, copper $(\mathrm{Cu})$, manganese $(\mathrm{Mn})$, nickel $(\mathrm{Ni})$, chromium $(\mathrm{Cr})$, selenium (Se). Although heavy metals were determined in some honey samples, honey samples in this study was found to be reliable in terms of heavy metal residues. Additionally, consumption of the food samples with high heavy metal residues can lead to serious health manifestations.

\section{Acknowledgement}

Pollen analyses in the this study was supported by the Comission of Scientific Researches Projects (Mustafa Kemal University), Proje number: BAP-409.

\section{REFERENCES} $37: 1-18$.

Bogdanov S. Contaminants of Bee Products. Apidologie, 2006;

Bilandžić N, Gačić M, Đokić M, Sedak M, Šipušić ĐI, Končurat A, Gajger IT. Major and trace elements levels in multifloral and unifloral honeys in Croatia. Journal of Food Composition and Analysis, $2014 ; 33: 132-138$.

Celli G, Maccagnanı B. Honeybees as bioindicators of environmental pollution. In Bulletin of Insectology, 2003; 56:137-139.

Crane E. Bees, honey and pollen as indicators of metals in the envirnment.- Bee World, 1984; 55:47-49.

Chudzinska M, Baralkiewicz D, Application of ICP-MS method of determination of 15 elements in honey with chemometric approach for the verification of their authenticity. Food and Chemical Toxicology, 2011; 49:2741-2749.

Czipa N, Andrasi D, Kovacs B. Determination of essential and toxic elements in Hungarian honeys. Food Chemistry, 2015; 175:536-542

Dean JR. 2003. Methods for environmental trace analysis: In: David JA, ed. Northumria University, Newcastle, UK: John Wiley \& Sons Ltd, England 1-257.

Gül A. 2008.The investigation of textural characteries of some Turkish honeys, with respect to food safety. Doctoral thesis. Hatay/TURKEY

Haddad HH. 2012. The Effect of Heavy Metals Cadimium, Chromium and Iron Accumulation in Human Eyes. American Journal of Analytical Chemistry, 2012; 3:710-713

Halliwell B and Gutteridge TM. 1999. Free Radicals in Biology and Medicine. Oxford University Press, Oxford

Formicki G, Greń A, Stawarz R, Zyśk B, Gał A. Metal Content in Honey, Propolis, Wax and Bee Pollen and Implications for Metal Pollution Monitoring. Pol. J. Environ. Stud., 2013; 22/1:99-106.
Maurizio A. Pollen Analysis of honey. Bee World, 1951; (32):1-5.

Nanda V, Sarkar BC, Sharma HK, Bawa A.S. Physico-chemical properties and estimation of mineral content in honey produced from different plants in Northern India. J. Food Compos. Anal, 2003; 16:613619.

Pisani A, Protano G, Riccobono F. Minor and trace elements in different honey types produced in Siena County (Italy). Food Chemistry, 2008; 107:1553-1560.

Porrini C, Sabatini AG, Girotti S, Ghini S, Medrzycki P, Grillenzoni F, Bortolotti L, Gattavecchia E, Celli G. Honey bees and bee products as monitors of the environmental contamination. Apiacta, 2003; 38:63-70.

Pulido MD andParrish AR. Metal Induced Apoptosis Mechanisms. Mutation Research, 2003; 533:227-241.

$\mathrm{Ru}$ QM, Feng Q, He J. Risk assessment of heavy metals in honey consumed in Zhejiang province, southeastern China. Food and Chemical Toxicology, 2013; 53:256-262.

Sataray S, Baker JB, Curbenjapol S. A Global Perspective on Cadimium Pollution and Toxicity in Non- Occupationally Exposed Population. Toxicology Letters, 2003; 137:65-83.

Silici S, Uluozlu OD, Tuzen M, Soylak M. Assessment of trace element levels in Rhododendron honeys of Black Sea Region, Turkey. Journal of Hazardous Materials, 2008; (156):612-618

Silici S, UluozluOD, Tuzen M, Soylak M. Honey bee and honey as monitors for heavy metal contamination near the thermal power plants in Mugla, Turkey. Toxicology and Industrial Health, 2014; 1-10

Terrab A, Recamales AF, González Miret ML, Heredia FJ. Contribution to the study of avocado honeys by their mineral contents using inductively coupled plasmaoptical emission spectrometry. Food Chemistry, 2005; 92:305-309.

Tuzen M. Determination of some metals in honey samples for monitoring environmental pollution. Fresenius Environ. Bull, 2002; (11):366-370.

Weast RC. 1984. CRC Handbook of Chemistry and Physics, 64th ed. Boca Raton, FL: CRC Press.

\section{How to cite this article:}

Tuba Pehlivan and Aziz Gül. Determination of Heavy Metals Contents of Some Monofloral Honey Produced in Turkey. J App Pharm Sci, 2015; 5 (08): 042-045. 